\title{
PENGARUH PENGETAHUAN, SIKAP, DAN SUMBER INFORMASI TERHADAP KEKERASAN DALAM PACARAN DI SMA BINA CIPTA PALEMBANG TAHUN 2018
}

\author{
Sri Emilda \\ Program Studi D IV Kebidanan STIKES Mitra Adiguna Palembang \\ Komplek Kenten Permai Blok J No. 9-12 Bukit Sangkal Palembang 30114 \\ Email : sriemilda1@gmail.com
}

\begin{abstract}
Abstrak
Masyarakat banyak yang perduli tentang kekerasan yang terjadi di dalam rumah tangga (domestic violence), namun masih sedikit yang peduli pada kekerasan yang terjadi pada mereka yang sedang berpacaran (Kekerasan Dalam Pacaran/ KDP) atau Dating Violence. Kekerasan dalam pacaran dapat berupa kekerasan fisik, psikis, emosional, atau seksual. Penelitian ini bertujuan untuk mengetahui Pengaruh Pengetahuan, Sikap, dan Sumber Informasi terhadap Kekerasan Dalam Pacaran di SMA Bina Cipta Kota Palembang Tahun 2018. Penelitian ini adalah penelitian analitik dengan menggunakan rancangan penelitian cross sectional dengan populasi seluruh siswa kelas XI SMA Bina Cipta Kota Palembang tahun 2018 yang berjumlah 273 orang dan jumlah sampel 65 orang siswa perempuan kelas $X I$, pengambilan sampel dilakukan dengan teknik Non Random dengan metode purposive sampling dengan uji Chi-Square. Hasil penelitian ini menunjukkan bahwa ada pengaruh pengetahuan terhadap kekerasan dalam pacaran dengan p value 0,001, ada pengaruh sikap terhadap kekerasan dalam pacaran dengan $p$ value 0,016, dan ada pengaruh sumber informasi terhadap kekerasan dalam pacaran dengan p value 0,006. Dari hasil penelitian tersebut dapat disimpulkan bahwa ada pengaruh pengetahuan, sikap, dan sumber informasi terhadap kekerasan dalam pacaran di SMA Bina Cipta Kota Palembang Tahun 2018.
\end{abstract}

Kata Kunci : Pengetahuan, Sikap, Sumber Informasi dan Kekerasan dalam Pacaran

\begin{abstract}
Many people care about domestic violence, but there are still a few who care about the violence that happens to those who are dating (Dating Violence / KDP) or Dating Violence. Dating violence can be physical, psychological, emotional or sexual violence. This study aims to determine the Influence of Knowledge, Attitudes, and Sources of Information on Dating Violence in Palembang City Bina Cipta High School in 2018. This study is an analytical study using a cross sectional study design with a population of all class XI Palembang Bina Cipta High School students in 2018 which amounted to 273 people and a sample of 65 female students of class XI, sampling was done by Non Random technique with a purposive sampling method with Chi-Square test. The results of this study indicate that there is an influence of knowledge on dating violence with $p$ value 0.001, there is an influence of attitudes toward dating violence with $p$ value 0.016, and there is an influence of information sources on dating violence with $p$ value 0.006. From the results of these studies it can be concluded that there is an influence of knowledge, attitudes, and sources of information on violence in courtship in Palembang City Bina Cipta High School in 2018.
\end{abstract}

Keywords: Knowledge, Attitude, Source of Information and Violence in Dating 


\section{PENDAHULUAN}

Kekerasan (violence) merupakan tindakan yang disengaja berupa kekerasan fisik atau ancaman terhadap diri sendiri, orang lain, dan kelompok yang saat ini menjadi masalah kesehatan global dengan proporsi epidemi (Satriyandari, 2017).

Laporan WHO tahun 2002 mengenai "Violence dan Health" menunjukan bahwa kualitas kesehatan perempuan menurun drastis akibat kekerasan yang dialaminya. Kematian wanita mencapai antara 40-70\% akibat pembunuhan umumnya dilakukakan oleh pasangannya sendiri. Di Amerika Serikat data statistik disana menunjukan bahwa setiap 9 menit perempuan menjadi korban kekerasan fisik, dan $25 \%$ perempuan yang terbunuh oleh pasangan lelakinya (Indrie, 2013).

Sasaran kelima dari Sustainable Development Goals (SDG's) yaitu menjamin kesetaraan gender dengan salah satu target menghilangkan segala bentuk kekerasan terhadap seluruh perempuan. Menurut (WHO, 2013), kekerasan (violence) merupakan tindakan yang disengaja berupa kekerasan fisik atau ancaman terhadap diri sendiri, orang lain, dan kelompok yang saat ini menjadi masalah kesehatan global dengan proporsi epidemi (Satriyandari, 2017).

Masyarakat banyak yang peduli tentang kekerasan yang terjadi di dalam rumah tangga (domestic violence), namun masih sedikit yang peduli pada kekerasan yang terjadi pada mereka yang sedang berpacaran (Kekerasan Dalam Pacaran/ KDP) atau Dating Violence. Perempuan lebih banyak menjadi korban dibandingkan laki-laki karena pada dasarnya kekerasan ini terjadi karena adanya ketimpangan kekuasaan antara laki-laki dan perempuan yang dianut oleh masyarakat luas. Ketidakadilan dalam hal gender selama ini telah terpatri dalam kehidupan sehari-hari, bahwa seorang perempuan biasa dianggap sebagai makhluk yang lemah, penurut, pasif, mengutamakan kepentingan laki-laki dan lain sebagainya, sehingga dirasa "pantas" menerima perlakuan yang tidak wajar atau semena-mena (Musvita, 2012).

Catatan Tahunan (CATAHU) Komnas Perempuan tahun 2018 menunjukkan hal yang abru, berdasarkan laporan kekerasan di ranah privat/personal yang diterima mitra pengadalayanan, terdapat angka kekerasan terhadap anak perempuan yang meningkat dan cukup besar yaitu sebanyak 2.227 kasus, dan kemudian kekerasan terhadap istri tetap menempati peringkat pertama yakni 5.167 kasus, dan kemudian kekerasan dalam pacaran merupakan angka ketiga terbanyak setelah kekerasan terhadap anak yaitu 1.873 kasus.

CATAHU juga menemukan bahwa dari total 2.979 kasus kekerasan seksual, pelaku kekerasan seksual tertinggi di ranah privat/personal adalah pacar sebanyak 1.528 orang, diikuti ayah kandung sebanyak 425 orang, kemudian diperingkat ketiga adalah paman sebanyak 322 orang (Komnasperempuan.go.id>pdf_file>2018).

Kasus kekerasan dalam pacaran di Kota Palembang, Sumatera Selatan (Sum.Sel), terbilang tinggi. Tercatat sudah ada 10 laporan sepanjang 2018. Demikian menurut data Women Crisis center (WCC). "Ini yang melaporkan saja. Belum lagi yang tidak melapor masih sangat banyak," kata Direktur WCC Palembang Yeni Roslaini Izi saat dihubungi JawaPos.com, Selasa (6/11). Menurut Yeni, kasus kekerasan dalam pacaran seperti gunung es. Sebab korban yang tidak melapor lebih banyak dibandingkan angka resminya setiap tahun.

Direktur eksekutif WCC Palembang, Yeni Roslaini Izi mengatakan pihaknya mengkategorikan Kekerasan Dalam Pacaran 
(KDP) menjadi tiga, yakni kekerasan seksual berupa sikap tidak bertanggung jawab laki-laki setelah menghamili seorang wanita, kekersan fisik dan hutang (laki-laki yang gemar berhutang dengan pasangannya tapi akhirnya ditinggalkan)(sripoku.com, 2018).

Salah satu faktor yang dapat menyebabkan KDP atau dating violence adalah pengetahuan tentang dating violence itu sendiri. Pengetahuan yang baik tentang bentuk dan dampak kekerasan dapat mengindikasikan resiko yang lebih rendah untuk tindakan kekerasan yang dilakukan oleh teman atau orang terdekat (pacar) akan tetapi remaja mengetahui tindakan yang mereka terima adalah bentuk kekerasan tetapi tidak mampu menolak atau menghindari kekerasan tersebut sehingga kejadian tersebut tidak dapat dihindari (Rahima, 2013).

Hal ini sesuai dengan penelitian yang dilakukan Purnama (2017), yaitu terdapat hubungan antara pengetahuan dengan kejadian dating violance. Setelah dilakukan penelitian terhadap 124 responden, didapatkan hasil sebanyak 81 responden mengalami kejadian dating violance dengan pengetahuan baik sebanyak 108, pengetahuan cukup sebanyak 9 orang mahasiswi dan pengetahuan kurang 7 orang.

Menurut YLKI, kekerasan dalam pacaran sering juga disebabkan oleh sikap dari perempuan atau remaja putri itu sendiri. Tidak jarang seorang perempuan yang sedang mengalami masa pubertas dan sedang jatuh cinta pada laki-laki menerima dengan begitu saja perlakuan dari kekasihnya. Ia melakukan hal tersebut karena takut diputuskan cintanya atau ditolak laki-laki tersebut. Kenyataan menjadi "jomblo" yang tidak disukai oleh para remaja menyebabkan mereka memilih untuk tetap berpacaran meskipun dengan laki-laki yang jahat. Sikap dan keyakinan seperti ini yang menyebabkan remaja cenderung mengalami kekerasan dalam pacaran (Ariestina, 2009).

Penelitian yang dilakukan oleh Maulidta (2015), terdapat variabel yang memiliki hubungan dengan perilaku kekerasan dalam pacaran siswi SMA " $X$ " di Kota Semarang yaitu usia responden, tingkatan kelas respoden, sikap responden, akses responden responden, peran keluarga responden, dan peran teman.

Sedangkan menurut Ariestina (2009), informasi yang benar dan cukup tentang kekerasan dan bentuk-bentuk kekerasan akan membuat remaja mengerti dan memahami tentang praktik kekerasan yang mereka alami, mereka cenderung terhindar dari bentuk-bentuk perlakuan kekerasan baik secara fisik maupun, maupun nonfisik. Informasi ini dapat didapatkan dari orangtua, guru, teman dan media massa.

Sejalan dengan penelitian yang dilakukan Musvita (2012), Sumber informasi yang didapat remaja putri bukan dari orang tua melainkan media massa (media cetak dan media elektronik) sebanyak 23,46\%. Hasil uji statistik menunjukkan hubungan yang bermakna antara sumber informasi bukan dari orang tua tetapi dari media massa dengan remaja yang mengalami kekerasan dalam pacaran.

Berdasarkan data yang didapat dari SMA Bina Cipta Kota Palembang tahun 2018, diketahui terdapat 273 orang siswa yang terdiri dari 71 siswa perempuan dan 47 siswa laki-laki di kelas $X, 65$ siswa perempuan dan 32 siswa laki-laki di kelas XI, serta 32 siswa perempuan dan 26 siswa laki-laki di kelas XII (Profil, SMA Bina Cipta 2018).

Perhatian terhadap kekerasan dalam pacaran yang masih terbatas membuat penulis tertarik untuk meneliti Pengaruh Pengetahuan, Sikap, dan Sumber Informasi terhadap Kekerasan Dalam Pacaran di SMA Bina Cipta Kota Palembang tahun 2018. 


\section{METODE PENELITIAN}

\section{Ruang Lingkup Penelitian}

Penelitian ini adalah jenis penelitian analitik. Penelitian bertujuan untuk mengetahui pengaruh pengetahuan, sikap , dan sumber informasi terhadap kekerasan dalam pacaran di SMA Bina Cipta Palembang Tahun 2018.

\section{Format Penelitian}

Penelitian ini melakukan pengukuran pada variabel bebas (independen) dan terikat (dependen) kemudian menganalisis data yang terkumpul untuk mencari pengaruh antar variabel. Penelitian ini merupakan penelitian cross sectional yang merupakan suatu penelitian untuk mempelajari dinamika kolerasi antara faktor-faktor resiko dengan efek, dengan cara pendekatan, observasi, atau pengumpulan data sekaligus pada suatu saat.

Variabel penelitian :

a. Variabel bebas (independent variable) dalam penelitian ini adalah pengetahuan, sikap, dan sumber informasi responden terhadap kekerasan dalam pacaran.

b. Variabel terikat (dependent variable) dalam penelitian ini adalah kekerasan dalam pacaran di SMA Bina Cipta Palembang tahun 2018.

\section{Waktu Penelitian}

Penelitian ini dilakukan pada tanggal 14 Juli 2018.

\section{Tempat Penelitian}

Penelitian ini dilakukan di SMA Bina Cipta Palembang.

\section{Data dan Teknik Pengumpulan Data Data}

Dalam penelitian ini untuk memperoleh data variabel independen (pengetahuan, sikap, dan sumber informasi responden terhadap kekerasan dalam pacaran) peneliti menggunakan data primer yang diperoleh dari wawancara dan pengisian kuesioner.

\section{Teknik Pengumpulan Data}

Teknik pengumpulan data adalah suatu proses pendekatan kepada subjek dan proses pengumpulan karakteristik subjek yang diperlukan dalam suatu penelitian. Sebelum pengumpulan data, perlu dilihat alat ukur pengumpulan data agar dapat memperkuat hasil penelitian. Alat ukur pengumpulan data tersebut antara lain dapat berupa kuesioner, observasi, wawancara atau gabungan ketiganya. Dalam penelitian ini peneliti menggunakan kuesioner sebagai alat dalam pengumpulan data.

\section{Populasi dan Sampel Populasi}

Jumlah populasi sebanyak 273 siswa SMA Bina Cipta Palembang.

\section{Sampel Penelitian}

Sampel penelitian ini adalah siswa perempuan kelas XI sebanyak 65 siswa. Pengambilan sampel ini dilakukan dengan teknik Non Random dengan metode purposive sampling yaitu pengambilan sampel secara purposive didasarkan pada suatu pertimbangan yang dibuat oleh peneliti sendiri, berdasarkan ciri atau sifatsifat populasi yang sudah diketahui sebelumnya.

1. Kriteria inklusi

1) Bersedia menjadi responden

2) Hadir pada saat penelitian

3) Siswa kelas XI

4) Siswa perempuan yang pernah/ sedang berpacaran

2. Kriteria eksklusi

1) Tidak bersedia menjadi responden

2) Tidak hadir saat penelitian 
3) Siswa kelas X dan XII

4) Siswa perempuan yang pernah/ sedang berpacaran

\section{Teknik Analisis Data}

\section{Analisa Data Univariat}

Analisa univariat dilakukan terhadap tiap variabel dari hasil penelitian yaitu variabel independen (pendidikan, pekerjaan,ekonomi) yang di analisis dengan menggunakan tabel distribusi frekuensi.

\section{Analisa Bivariat}

Analisa bivariat adalah analisa data untuk mengetahui hubungan antara variabel independen dengan variabel dependen yang di analisis dengan uji chi-square $\left(\mathrm{x}^{2}\right)$ dengan taraf signifikan $(\alpha)=0,05$.

1. Jika $p$ value $\leq$ nilai $\alpha$ adalah $(0,05)$. Maka ada hubungan antara variabel independen dengan variabel dependen.

2. Jika $p$ value $>$ nilai $\alpha$ adalah $(0,05)$. Maka tidak ada hubungan bermakna (signifikan) antara variabel independen dengan variabel dependen.

\section{HASIL PENELITIAN DAN PEMBAHASAN}

Tabel 1. Distribusi Frekuensi Kejadian Kekerasan Dalam Pacaran di SMA Bina Cipta Kota Palembang Tahun 2018

\begin{tabular}{llcc}
\hline No. & $\begin{array}{c}\text { Kekerasan } \\
\text { Dalam Pacaran }\end{array}$ & Frekuensi & \% \\
\hline 1 & Tidak & 50 & 76,9 \\
2 & Ya & 15 & 23,1 \\
\hline & Jumlah & 65 & 100 \\
\hline
\end{tabular}

Tabel 2. Distribusi Frekuensi Berdasarkan Pengetahuan di SMA Bina Cipta Kota Palembang Tahun 2018

\begin{tabular}{clcc}
\hline No. & Pengetahuan & Frekuensi & \% \\
\hline 1 & Baik & 46 & 70,9 \\
2 & Kurang & 19 & 29,2 \\
\hline & Jumlah & 65 & 100 \\
\hline
\end{tabular}

Tabel 3. Distribusi Frekuensi Berdasarkan Sikap di SMA Bina Cipta Kota Palembang Tahun 2018

\begin{tabular}{clcc}
\hline No. & Sikap & Frekuensi & \% \\
\hline 1 & Positif & 38 & 58,5 \\
2 & Negatif & 27 & 41,5 \\
\hline & Jumlah & 65 & 100
\end{tabular}


Tabel 4. Distribusi Frekuensi Berdasarkan Sumber Informasi di SMA Bina Cipta Kota Palembang Tahun 2018

\begin{tabular}{llcc}
\hline No. & $\begin{array}{l}\text { Sumber } \\
\text { Informasi }\end{array}$ & Frekuensi & \% \\
\hline 1 & Ya & 43 & 66,2 \\
2 & Tidak & 22 & 33,8 \\
\hline & Jumlah & 65 & 100 \\
\hline
\end{tabular}

Tabel 5. Pengaruh Pengetahuan terhadap Kekerasan Dalam Pacaran di SMA Bina Cipta Kota Palembang Tahun 2018

\begin{tabular}{|c|c|c|c|c|c|c|c|c|}
\hline \multirow{4}{*}{ No } & \multirow{4}{*}{ Pengetahuan } & \multicolumn{4}{|c|}{ Kekerasan Dalam } & \multirow{4}{*}{$\mathbf{N}$} & \multirow{4}{*}{$\%$} & \multirow{4}{*}{$\begin{array}{c}P \\
\text { Value }\end{array}$} \\
\hline & & & Pac & an & & & & \\
\hline & & \multicolumn{2}{|c|}{ Tidak } & \multicolumn{2}{|c|}{$\mathrm{Ya}$} & & & \\
\hline & & $\mathrm{n}$ & $\%$ & $\mathrm{n}$ & $\%$ & & & \\
\hline 1 & Baik & 41 & 89,1 & 5 & 10,9 & 46 & 100 & \multirow{3}{*}{0,001} \\
\hline \multirow[t]{2}{*}{2} & Kurang & 9 & 47,4 & 10 & 52,6 & 19 & 100 & \\
\hline & Jumlah & 50 & & 15 & & 65 & & \\
\hline
\end{tabular}

Tabel 6. Pengaruh Sikap terhadap Kekerasan Dalam Pacaran di SMA Bina Cipta Kota Palembang Tahun 2018

\section{Kekerasan Dalam}

\begin{tabular}{|c|c|c|c|c|c|c|c|c|}
\hline & \multirow{3}{*}{ Sikap } & \multicolumn{4}{|c|}{ Pacaran } & \multirow{3}{*}{$\mathbf{N}$} & \multirow{3}{*}{$\%$} & \multirow{3}{*}{$\begin{array}{c}P \\
\text { Value }\end{array}$} \\
\hline & & \multicolumn{2}{|c|}{ Tidak } & \multicolumn{2}{|c|}{$\mathrm{Ya}$} & & & \\
\hline & & $\mathrm{n}$ & $\%$ & $\mathrm{n}$ & $\%$ & & & \\
\hline 1 & Positif & 33 & 89,2 & 4 & 10,8 & 37 & 100 & \\
\hline 2 & Negatif & 17 & 60,7 & 11 & 39,3 & 28 & 100 & 0,016 \\
\hline & Jumlah & 50 & & 15 & & 65 & & \\
\hline
\end{tabular}

Tabel 7. Pengaruh Sumber Informasi terhadap Kekerasan Dalam Pacaran di SMA Bina Cipta Kota Palembang Tahun 2018

\section{Kekerasan Dalam}

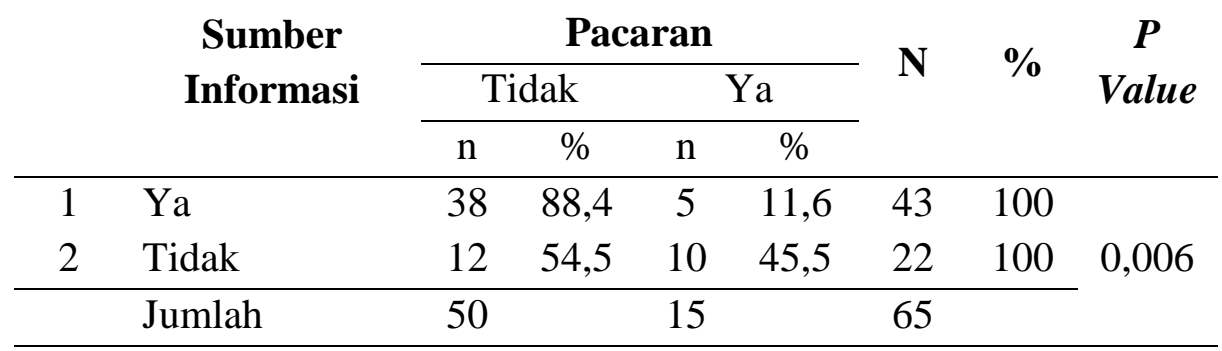




\section{Pengaruh Pengetahuan Terhadap Kekerasan Dalam Pacaran}

Berdasarkan analisis univariat diketahui distribusi frekuensi responden dengan pengetahuan kategori baik sebanyak 46 orang $(70,9 \%)$, lebih banyak dibandingkan dengan responden dengan pengetahuan kurang sebanyak 19 orang $(29,2 \%)$.

Berdasarkan analisis bivariat diketahui dari 46 responden yang memiliki pengetahuan baik terdapat 41 responden $(89,1 \%)$ yang tidak mengalami kekerasan dalam pacaran dan 5 responden $(10,9 \%)$ yang mengalami kekerasan dalam pacaran

Dari hasil uji chi-square, didapat nilai $p$ value $0,001<\alpha 0,05$, hal ini menunjukkan bahwa ada pengaruh pengetahuan terhadap terjadinya kekerasan dalam pacaran di SMA Bina Cipta Kota Palembang tahun 2018, sedangkan nilai $\mathrm{OR}=9,111$ hal ini menunjukkan bahwa pengetahuan yang baik lebih tinggi 9,111 kali untuk tidak mengalami kekerasan dalam pacaran dibandingkan dengan pengetahuan kurang. Dengan demikian hipotesa awal ada pengaruh pengetahuan terhadap kekerasan dalam pacaran di SMA Bina Cipta Kota Palembang Tahun 2018 terbukti secara statistik.

$$
\text { Menurut Notoatmodjo (2014) }
$$

Pengetahuan adalah hasil pengindraan manusia, atau hasil tahu seseorang terhadap objek melalui indra yang dimilikinya (mata, hidung, telinga, dan sebagainya). Dengan sendirinya pada waktu pengindraan sehingga menghasilkan pengetahuan tersebut sangat dipengaruhi oleh intensitas perhatian dan presepsi terhadap objek. Sebagian besar pengetahuan seseorang diperoleh melalui indra pendengaran (telinga), dan indra penglihatan (mata). Pengetahuan diperoleh dari pengalaman sendiri maupun pengalaman orang lain.
Teori ini sejalan dengan teori Notoatmodjo (2013) dalam jurnal Dina Purnama Sari dan Yekti Satriyandari (2017) tentang Hubungan Pengetahuan Dengan Kejadian Dating Violence Pada Mahasiswa Prodi Bidan Pendidik Jenjang Diploma IV di Universitas 'Aisyiyah Yogyakarta, pengetahuan merupakan domain yang sangat penting untuk terbentuknya tindakan seseorang karena dengan pengetahuan yang baik dapat menciptakan perilaku dan sikap yang baik dalam pacaran.

Menurut Callahan, Tolman, \& Saunders (2003) dalam jurnal Elisabeth Haksi Mayawati (2009) tentang Pengetahuan Remaja Tentang Fenomena kekerasan dalam pacaran, kekerasan dalam pacaran menimbulkan dampak negatif yang tidak bisa dikatakan ringan. Kekerasan dalam pacaran dapat menimbulkan stres paska trauma, gejala disoasiatif, kecemasan, dan depresi.

Hal ini sejalan dengan dengan teori Rahima (2013), yang menyatakan bahwa pengetahuan yang baik tentang bentuk dan dampak kekerasan mengindikasikan resiko yang lebih rendah untuk tindakan kekerasan yang dilakukan oleh teman atau oleh orang terdekat (pacar).

Namun penelitian ini tidak sejalan dengan penelitian yang dilakukan oleh Nurul Izzati (2013) mengenai Hubungan Pengetahuan dan Sikap Terhadap Kekerasan Dalam Pacaran pada Siswa kelas XI SMA Negeri 113 Jakarta Tahun 2012, penelitian ini menunjukkan dari 88 reponden yang berpengetahuan tinggi hanya terdapat $89,8 \%$ (79 responden) yang pernah mengalami kekerasan dalam pacaran. Dari 50 responden yang berpengetahuan rendah terdapat $94 \%$ (47) responden yang pernah mengalami kekerasan dalam pacaran. Berdasarkan hasil uji statistik Chi-Square terlihat bahwa tidak ada hubungan bermakna antara kejadian kekerasan dalam pacaran dengan $P$ value 
pengetahuan $0,536>\alpha 0,05$. Hal ini dapat terjadi dikarenakan remaja mengetahui tindakan yang mereka terima adalah bentuk kekerasan tetapi tidak mampu menolak atau menghindari kekerasan tersebut sehingga kejadian tersebut tidak dapat dihindari.

Dari hasil penelitian dan teori yang ada, peneliti berpendapat bahwa pengetahuan berpengaruh terhadap kekerasan dalam pacaran. Karena semakin baik pengetahuan tentang kekerasan dalam pacaran maka dapat menghindari dari perlakuan yang salah yaitu kekerasan dalam pacaran.

\section{Pengaruh Sikap Terhadap Kekerasan Dalam Pacaran}

Berdasarkan analisis univariat diketahui distribusi frekuensi responden dengan sikap kategori positif sebanyak 38 orang $(58,8 \%)$, lebih banyak dibandingkan dengan responden dengan sikap negatif sebanyak 27 orang $(41,5 \%)$.

Berdasarkan analisis bivariat diketahui dari 37 responden yang memiliki sikap positif terdapat 33 responden $(28,5 \%)$ yang tidak mengalami kekerasan dalam pacaran dan 4 responden $(8,5 \%)$ yang mengalami kekeraan dalam pacaran

Dari hasil uji chi-square, didapat nilai $p$ value $0,016<\alpha 0,05$, hal ini menunjukkan bahwa ada pengaruh pengetahuan terhadap terjadinya kekerasan dalam pacaran di SMA Bina Cipta Kota Palembang tahun 2018, sedangkan nilai $\mathrm{OR}=5,338$ hal ini menunjukkan bahwa sikap yang positif lebih tinggi 5,338 kali untuk tidak mengalami kekerasan dalam pacaran dibandingkan dengan sikap negatif. Dengan demikian hipotesa awal ada pengaruh sikap terhadap kekerasan dalam pacaran di SMA Bina Cipta Kota Palembang Tahun 2018 terbukti secara statistik.

Menurut Notoatmodjo (2014), Sikap merupakan penilaian yang menyeluruh terhadap perilaku atau tindakan yang akan di ambil. Sikap menggambarkan suka atau tidak suka seseorang terhadap objek. Sikap adalah bagaimana pendapat atau penilaian orang atau responden terhadap hal yang terkait dengan kesehatan, sehat-sakit dan faktor-faktor yang terkait dengan faktor resiko.

Menurut Kusmiran (2012) dalam Jurnal Khusniyah Hindun dan Tri Wahyuning Pujiastuti (2017) tentang Hubungan Persepsi Remaja Tentang Kekerasan Dalam Pacaran Dengan Sikap Remaja Terhadap Kekerasan Dalam Pacaran Pada Siswa SMA Muhammadiyah 7 Yogyakarta, sikap perempuan yang terlalu permisif juga dianggap memicu timbulnya masalah pelecehan seksual dan kekerasan nonseksual. Sikap seseorang dapat dipengaruhi oleh beberapa faktor diantaranya faktor eksternal dimana keadaan-keadaan yang ada di luar individu yang merupakan stimulus untuk membentuk atau mengubah sikap.

Menurut Ferlita (2008), dalam jurnal Anisa Nurhaniya (2016) tentang Sikap terhadap Kekerasan dalam Berpacaran Pada Mahasiswa, Setiap orang memiliki keunikan masing-masing dan memiliki sikap yang berbeda-beda dalam melihat kekerasan yang terjadi dalam suatu hubungan berpacaran. Ada yang bersikap menerima dan menganggap kekerasan merupakan hal yang wajar atau wujud cinta kasih dari pasangan dan ada pula yang bersikap membenci dan menjauhi kekerasan dalam suatu hubungan.

Menurut YLKI, kekerasan dalam pacaran sering juga disebabkan oleh sikap dari perempuan atau remaja putri itu sendiri. Tidak jarang seorang perempuan yang sedang mengalami masa pubertas dan sedang jatuh cinta pada laki-laki menerima dengan begitu saja perlakuan dari kekasihnya. Ia melakukan hal tersebut karena takut diputuskan cintanya atau ditolak laki-laki tersebut. Kenyataan menjadi "jomblo" yang tidak disukai oleh 
para remaja menyebabkan mereka memilih untuk tetap berpacaran meskipun dengan laki-laki yang jahat. Sikap dan keyakinan seperti ini yang menyebabkan remaja cenderung mengalami kekerasan dalam pacaran (Ariestina, 2009).

Hasil penelitian ini sejalan dengan penelitian Dian Arestina (2009), yang berjudul Kekerasan dalam Pacaran pada Siswi SMA di Jakarta dengan sikap responden terhadap kejadian Kekerasan Dalam Pacaran setelah dilakukan uji statistik didapatkan nilai $\mathrm{p}=0,031 \quad(\mathrm{p}<0,05)$, dan didapatkan nilai OR adalah 1,5 , itu artinya ada pengaruh sikap remaja dengan kejadian KDP dan remaja yang memiliki sikap yang negatif 1,5 kali lebih besar mengalami KDP.

Berdasarkan hasil penelitian dan teori di atas, peneliti berpendapat bahwa sikap berpengaruh terhadap kekerasan dalam pacaran, karena sikap yang positif dapat menghindarkan remaja putri terhadap kekerasan dalam pacaran.

\section{Pengaruh Sumber Informasi Terhadap Kekerasan Dalam Pacaran}

Berdasarkan analisis univariat diketahui distribusi frekuensi responden dengan sumber informasi dari orang tua sebanyak 43 orang $(66,2 \%)$, lebih banyak dibandingkan dengan responden yang mendapatkan informasi bukan dari orang tua sebanyak 22 orang $(33,8 \%)$.

Berdasarkan analisis bivariat diketahui dari 43 responden yang mendapatkan sumber informasi dari orang tua terdapat 38 responden $(33,1 \%)$ yang tidak mengalami kekerasan dalam pacaran dan 5 responden $(9,9 \%)$ yang mengalami kekerasan dalam pacaran.

Dari hasil uji chi-square, didapat nilai $p$ value $0,006<\alpha 0,05$, hal ini menunjukkan bahwa ada pengaruh sumber informasi terhadap terjadinya kekerasan dalam pacaran di SMA Bina Cipta Kota Palembang tahun
2018, sedangkan nilai $\mathrm{OR}=6,333$ hal ini menunjukkan bahwa yang mendapatkan sumber informasi dari orang tua lebih tinggi 6,333 kali untuk tidak mengalami kekerasan dalam pacaran dibandingkan dengan pengetahuan kurang. Dengan demikian hipotesa awal ada pengaruh sumber informasi terhadap kekerasan dalam pacaran di SMA Bina Cipta Kota Palembang Tahun 2018 terbukti secara statistik.

Menurut Notoatmodjo (2012), sumber informasi adalah asal dari suatu informasi atau data yang diperoleh.

Menurut Wiec Hary A. (1996), dalam Notoatmodjo (2012), informasi akan memberikan pengaruh pada pengetahuan seseorang. Meskipun seseorang memiliki pendidikan yang rendah tapi jika ia mendapatkan informasi yang baik dari berbagai media misalnya televisi, radio atau surat kabar, maka hal itu akan dapat meningkatkan pengetahuan seseorang.

Menurut Murray (2006) dalam jurnal Dukungan Sosial : Informasi Melalui Media Modul Terhadap Pengenalan Dating Violence Pada Remaja Di Program Studi Ilmu Keperawatan Universitas Sriwijaya Inderalaya (2015), Para remaja hendaknya lebih banyak meluangkan waktu untuk mencari informasi tentang tindakan KDP dan hal-hal yang dapat dilakukan untuk menghindari tindakan KDP tersebut melalui orangtua, guru, media massa, petugas kesehatan, dan lain-lain. Pemerintah/ Depkes/ Dikmenti/ pihak terkait lainnya diharapkan dapat memberikan penyuluhan atau pemberian informasi tentang bentukbentuk kekerasan dalam berpacaran, akibat, dan cara mengatasinya. Banyak pihak yang berperan sebagai sumber informasi yang dapat mempengengaruhi pembentukan sikap remaja, seperti orangtua, teman sebaya, pacar, guru atau sekolah, media massa, dan lain-lain. Namun, tidak semua sumber informasi memberikan sumber yang akurat, termasuk yang menyangkut dating violence, 
sehingga tidak semua sumber informasi bagi remajaakan membentuk sikap yang tidak mendukung dating violence.

Hal ini sejalan dengan Jurnal Ariestina (2009), tentang Kekerasan dalam Pacaran pada Siswi SMA di Jakarta, informasi yang benar dan cukup tentang kekerasan dan bentuk-bentuk kekerasan akan membuat remaja mengerti dan memahami tentang praktik kekerasan yang mereka alami, mereka cenderung terhindar dari bentukbentuk perlakuan kekerasan baik secara fisik maupun, maupun nonfisik.

Menurut teori Schnurr (2009), dalam jurnal Puspita Kurnia Dhewi (2014) tentang Hubungan Perilaku Orang Tua dalam Menginformasikan Pacaran Sehat dengan Sikap Terhadap Kekerasan Dalam Pacaran Pada Siswi SMK Taman Siswa Kulon Progo, Jika ditinjau lebih jauh sesungguhnya orang tua dapat mengarahkan anaknya pada suatu pendidikan yang sesuai dengan nilainilai dan norma masyarakat sehingga komunikasi akan membentuk suatu hubungan yang baik antara orang tua dan anak. Dalam aspek komunikasi, informasi mengenai pacaran sehat penting diberikan karena akan berdampak baik pada kehidupan sosial remaja.

Namun penelitian ini tidak sejalan dengan penelitian dari Suci Musvita Ayu dkk (2012), tentang Kekerasan dalam Pacaran Dan Kecemasan Remaja Putri di Kabupaten Purworejo, Hasil uji statistik menunjukkan hubungan yang bermakna antara sumber informasi bukan dari orang tua tetapi dari media massa (media cetak dan media elektronik) dengan remaja yang mengalami kekerasan dalam pacaran $(\mathrm{p}=$ 0,04).

Berdasarkan hasil penelitian dan teori diatas, peneliti berpendapat bahwa sumber informasi berpengaruh terhadap terjadinya kekerasan dalam pacaran karena semakin banyak informasi yang didapatkan tentang bentuk-bentuk kekerasan maka dapat memperkecil resiko menjadi korban kekerasan dalam pacaran.

\section{KESIMPULAN DAN SARAN Kesimpulan}

Dari hasil penelitian yang dilakukan di SMA Bina Cipta Kota Palembang tahun 2018 mengenai pengaruh pengetahuan, sikap, dan sumber informasi terhadap kekerasan dalam pacaran, maka dapat di simpulkan bahwa:

1. Ada Pengaruh Pengetahuan terhadap Kekerasan Dalam Pacaran di SMA Bina Cipta Kota Palembang Tahun 2018, dari hasil Chi-Square didapat nilai $p$ value $0,001<\alpha=0,05$.

2. Ada Pengaruh Sikap terhadap Kekerasan Dalam Pacaran di SMA Bina Cipta Kota Palembang Tahun 2018, dari hasil $p$ value $0,016<\alpha=0,05$.

3. Ada Pengaruh Sumber Informasi terhadap Kekerasan Dalam Pacaran di SMA Bina Cipta Kota Palembang Tahun 2018 , dari hasil $p$ value $0,006<\alpha=0,05$.

\section{Saran}

\section{Bagi Siswa}

Siswa diharapkan meningkatkan pengetahuan akan kekerasan dalam pacaran, mempunyai sikap yang positif terhadap kekerasan dalam pacaran dan dapat menyaring setiap informasi yang diterima akan manfaat dari pacaran agar dapat terhindar dari kekerasan dalam pacaran.

\section{Bagi STIKES Mitra Adiguna}

Peneliti berharap hasil penelitian ini dapat dijadikan sebagai bahan referensi dalam melakukan penelitian khususnya yang berhubungan dengan kekerasan dalam pacaran dan menambah kepustakaan STIKES Mitra Adiguna Palembang.

\section{Bagi Petugas Kesehatan}

Diharapkan bagi petugas kesehatan dapat meningkatkan upaya penyuluhan 
mengenai kekerasan dalam pacaran kepada masyarakat khususnya remaja untuk menambah pengetahuan dan menghindarkan remaja dari resiko kekerasan dalam pacaran.

\section{Bagi Peneliti Yang Akan Datang}

Pada penelitian yang akan datang diharapkan dapat menggunakan variabel yang lebih bervariasi dan mencakup penelitian yang lebih luas sehingga penelitian terhadap kekerasan dalam pacaran ini dapat terus berkembang.

\section{DAFTAR PUSTAKA}

Ariestina, Dian. 2009. Kekerasan dalam Pacaran pada Siswi SMA di Jakarta. Jurnal Kesehatan Masyarakat. Diakses 21 Februari 2018.

CATAHU, Komnas Perempuan, 2018, Komnasperempuan.go.id $>$ pdf_file $>20$ 18. Diakses tanggal 15 Maret 2018.

Indrie, Stefanie E. Mantiri, dkk . 2013. Hubungan Antara Usia Waktu Menikah Dengan Kejadian Kekerasan Dalam Rumah Tangga Di Manado Periode September 2012 - Agustus 2013. Diakses tanggal 21 Februari 2018.

Jawapos.com. Kasus Kekerasan 2018. Diakses 4 maret 2018

Kusmiran, 2012. Jurnal Khusniyah Hindun dan Tri Wahyuning Pujiastuti 2017

Musvita, Suci Ayu, dkk. 2012. Kekerasan dalam Pacaran dan Kecemasan Remaja Putri di Kabupaten Purworejo. Jurnal Kesehatan Masyarakat. Diakses tanggal 21 Februari 2018.

Notoatmodjo, Sukidjo. 2013. Metodelogi Penelitian Kesehatan. Jakarta : PT Asdi Mahasatya.

Notoatmodjo, Sukidjo. 2014. Ilmu Prilaku Kesehatan. Jakarta : Pt Rineka Cipta.

Prayanti, Mutia. 2011. Modul Mahasiswi Kekerasan Terhadap Perempuan dan
Anak. Yayasan Pendidikan Kesehatan Perempuan : Jakarta.

Profil SMA Bina Cipta Kota Palembang. 2018. Data Siswa. Palembang : SMA Bina Cipta Kota Palembang.

Purnama, Dian Sari. 2017. Naskah Publikasi Hubungan Pengetahuan dengan Kejadian Dating Violence Pada Mahasiswa Prodi Bidan Pendidik Jenjang Diploma IV di Universitas 'Aisyiyah Yogyakarta. Diakses tanggal 21 Februari 2018.

Rahima, S. (2013). Kekerasan Dalam Pacaran (KDP) (Sering) Tak Terlihat Tapi Nyata. Majalah Islam Untuk HakHak Perempuan. No 41 Th. XIII April 2013

Satriyandari, Yekti dan Mur Octaviani. 2017. Hubungan Penggunaan Jenis Media Massa Dengan Kejadian Dating Violence. Journal of Health Studies. Diakses tanggal 21 Februari 2018.

Sripoku.com, 2018. Kasus kekerasan di Sum.Sel 2018. Diakses 4 Maret 2018 